Pediat. Res. 4: 157-164 (1970)

Calorie restriction manganese

DNA protein synthesis liver RNA

\title{
Comparisons Between Nucleic Acids, Protein, Zinc, and Manganese in Rat Liver: A Relation Between Zinc and Ribonucleic Acid
}

\author{
Alan B.Holt, E.David Mellits and Donald B. Cheek ${ }^{[33]}$ \\ Division of Growth, Ghildren's Medical and Surgical Center, The Johns Hopkins Hospital, \\ Baltimore, Maryland, USA
}

\begin{abstract}
Extract
The relations of total zinc, manganese, nucleic acids, and protein in the livers of control, hypophysectomized, and calorie-restricted rats were evaluated by regression analysis and analysis of covariance (tables I through V).

The most striking findings were the demonstration of a continuous relation between RNA and zinc in the livers of the control rats and of experimental groups (fig.2), and an absolute increase in the content of manganese in the livers of the calorie-restricted animals (fig. 3).

It is suggested that zinc is important for the maintenance of ribonucleic acid synthesis and subsequent protein synthesis in mammalian tissues.
\end{abstract}

\section{Speculation}

In biological tissues, ribonucleic acid is a necessary precursor for protein synthesis; possibly zinc, acting as a cofactor, is of equal importance.

\section{Introduction}

In an earlier paper [3] it was reported that during a variety of circumstances affecting growth of rats (endocrine imbalance, calorie restriction) the ratios in liver of both zinc and ribonucleic acid to deoxyribonucleic acid appeared to parallel each other closely. This suggested that the two components were related within the cell. The present study was designed to examine the relation of zinc and manganese to nucleic acids and protein within the rat liver by more definitive statistical methods in order to strengthen or discard the previous finding.

Statistical analysis, namely regression analysis and analysis of covariance, was utilized to inspect the relation of total zinc $(\mathrm{Zn})$ and also total manganese $(\mathrm{Mn})$ in rat liver with the liver content of deoxyribonucleic acid (DNA), ribonucleic acid (RNA), and protein. These interrelations are considered for control rats, rats receiving adequate protein but inadequate calories, and for rats that had been hypophysectomized.

Regression equations presented in this communication contain a common factor, liver weight, through which both the dependent and independent variables are calculated. This, of course, leads to somewhat spurious correlations. The emphasis of the statistical analysis, however, is not on the fitted equations but on the comparisons of the sets of data by analysis of covariance. This permits comparisons of animals of varying ages and sizes in a way that is biologically meaningful.

Analysis of covariance affords a sensitive statistical method by which two regression lines may be compared to determine whether they are from two different pop- 
ulations or are composed of two samples from the same population. If they are from two different populations, further analysis allows the investigator to decide sequentially if the lines are of different slopes or if they are parallel.

The final analysis indicates a continuous relation between RNA and $\mathrm{Zn}$ content under the conditions studied and the biological implications that follow from this relation [29].

\section{Methods and Materials}

Control and 'calorie-restricted' animals correspond to groups $1 \mathrm{~A}-1 \mathrm{E}$ and group II, respectively, as previously reported [10]; hypophysectomized rats were described as group II in another communication [2].

Briefly, male rats of the Sprague-Dawley strain were obtained at 21 days of age [30]; at 23 days of age, they were placed in individual metabolic cages with tap water freely available.

The control group of this study were fed a laboratory ration [31] (23\% protein) ad libitum and were killed at $26,28,35,38$, and 49 days of age, respectively. The calorie-restricted group received the same ration [31] but restricted in quantity to the intake of hypophysectomized rats that had had their pituitaries removed at 21 days of age; both abnormal groups were killed at 38 and 49 days of age.

The methods used for the determination of nucleic acids, protein, and trace metals are documented elsewhere $[5,10]$. The total amounts of DNA, RNA, protein, $\mathrm{Zn}$, and $\mathrm{Mn}$ were calculated as the product of the individual liver weight and the concentration of the corresponding individual determinants.

Regression and covariance analysis are described in many texts concerned with statistics. In addition, a summary has been presented elsewhere [15]. We consider an alpha level ( $P$ value) equal to 0.05 as being of borderline significance and not significant statistically. Levels of $P<0.025$ were considered significant.

\section{Results}

The relations between total amounts of DNA, RNA, protein, $\mathrm{Zn}$, and $\mathrm{Mn}$ in the liver of normal rats were determined by regression analysis. It was found that these quantities essentially were linearly related to each other. The correlation coefficients were between 0.90 and 0.97 . The linear functions for normal rats are presented in table $\mathrm{I}$. These relations were of sufficient accuracy to allow comparisons with the abnormal groups of rats.

Linear analysis of covariance was used for statistical
Table I. Linear equations, normal rats

\begin{tabular}{lrr}
\hline Equation & $\mathrm{N}^{1}$ & Variance $^{2}$ \\
\hline $\mathrm{RNA}^{3}, \mathrm{DNA}^{4}$, and protein & & \\
$\mathrm{RNA}^{5}=10.3834+3.0646$ (DNA) & 32 & 118.18 \\
$\mathrm{RNA}=13.4214+0.0529$ (protein) & 33 & 45.76 \\
Protein $=-110.892+59.24034$ & 35 & 25,353 \\
$\quad(\mathrm{DNA})$ & & \\
$\mathrm{Zn}^{6}$ & & \\
$\mathrm{Zn}=-7.03624+3.17133$ (RNA) & 33 & 971.80 \\
$\mathrm{Zn}=14.107+0.1851$ (protein) & 45 & 634.76 \\
$\mathrm{Zn}=-7.52743+11.04712$ (DNA) & 44 & $1,403.33$ \\
$\mathrm{Mn}^{7}$ & & \\
$\mathrm{Mn}=0.72399+0.19505$ (RNA) & 33 & 3.204 \\
$\mathrm{Mn}=1.1973+0.012$ (protein) & 45 & 2.227 \\
$\mathrm{Mn}=-0.67934+0.74339$ (DNA) & 44 & 3.076 \\
\hline
\end{tabular}

$1 \mathrm{~N}=$ number of rats in sample.

${ }^{2}$ Variance $=$ variance about the fitted line.

${ }^{3} \mathrm{RNA}=$ total liver RNA, mg.

${ }^{4} \mathrm{DNA}=$ total liver DNA, mg.

${ }^{5}$ Protein $=$ total liver protein, $\mathrm{mg}$.

${ }^{6} \mathrm{Zn}=$ total liver $\mathrm{Zn}, \mu \mathrm{g}$.

${ }^{7} \mathrm{Mn}=$ total liver $\mathrm{Mn}, \mu \mathrm{g}$.

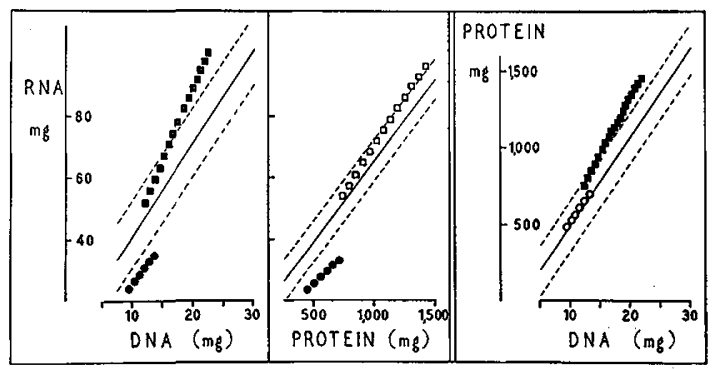

Fig. 1. Interrelation of nucleic acids and protein. Solid line represents the control. Dashed line represents the standard deviation. The equation to each normal relation is reported in the text. $\bigcirc \bullet$ : hypophysectomized rats. $\square$ : calorie-restricted rats. Solid symbols represent significant difference with controls by covariance analysis; open symbols represent nonsignificance. The length of the lines represent the range of data for each group.

comparison of these groups. These analyses are graphically illustrated in figures 1,2 , and 3 .

$R \mathcal{N} A, D \mathcal{N} A$, and Protein (table $I I$ )

Figure 1 shows that calorie-restricted rats consistently had higher total RNA and protein for a given DNA value $(P<0.001)$. Total RNA was slightly high for a given protein value although this difference was not significant statistically. 
In the liver of the hypophysectomized rats, the RNA content was reduced significantly from normal values when comparisons were made relative to protein or DNA $(P<0.001)$. The relation between protein and DNA, however, was similar to that of normal rats.

Zinc (table III)

In calorie-restricted rats, the relation between the amounts of $\mathrm{Zn}$ and RNA or of $\mathrm{Zn}$ and protein were not significantly different from normal animals (fig. 2). In these rats, $\mathrm{Zn}$ in the liver was high relative to DNA $(P<0.001)$.

Hypophysectomized rats appeared to have normal values for $\mathrm{Zn}$ relative to RNA and DNA. ${ }^{\text {r There was a }}$ significant difference $(P<0.01)$, however, in the amount of $\mathrm{Zn}$ relative to protein. The points for hypophysectomized rats formed a line that intersected the normal line. Due to the small range of protein values for these rats it is impossible to say whether they really departed from normal.

Thus, the relation between $\mathrm{Zn}$ and RNA did not depart from normal in either the calorie-restricted or the hypophysectomized rats. As a result, a linear equation combining all three groups was calculated:

$$
\mathrm{Zn}=18.4149+2.7831 \text { (RNA) }
$$

where $\quad \mathrm{N}=67$ and variance $=761.89$.

Table II. Govariance analysis

\begin{tabular}{|c|c|c|c|c|c|c|}
\hline \multirow[b]{3}{*}{ Source $^{1}$} & \multicolumn{6}{|c|}{ Control rats versus } \\
\hline & \multicolumn{3}{|c|}{ Hypophysectomized rats } & \multicolumn{3}{|c|}{ Calorie-restricted rats } \\
\hline & $\mathrm{df}^{2}$ & $\begin{array}{l}\text { Mean } \\
\text { square }\end{array}$ & $F$ & $\mathrm{df}$ & $\begin{array}{c}\text { Mean } \\
\text { square }\end{array}$ & $F$ \\
\hline \multicolumn{7}{|l|}{ RNA: DNA } \\
\hline $\begin{array}{l}\text { Reduction- } \\
\text { fitting two lines }\end{array}$ & 2 & 870.19 & $10.2991 * * *$ & 2 & $1,108.13$ & $11.2540 * * *$ \\
\hline $\begin{array}{l}\text { Reduction- } \\
\text { fitting two slopes }\end{array}$ & 1 & 2.89 & 0.0341 & 1 & 635.22 & $6.4512 *$ \\
\hline $\begin{array}{l}\text { Reduction- } \\
\text { fitting two means }\end{array}$ & 1 & $1,737.50$ & $20.5640 * * *$ & & & \\
\hline $\begin{array}{l}\text { Pooled error } \\
\text { SS about two lines }\end{array}$ & 45 & 84.49 & & 45 & 98.47 & \\
\hline \multicolumn{7}{|l|}{ RNA: protein } \\
\hline $\begin{array}{l}\text { Reduction- } \\
\text { fitting two lines }\end{array}$ & 2 & 886.47 & $26.0178 * * *$ & 2 & 152.15 & 3.7576 \\
\hline $\begin{array}{l}\text { Reduction- } \\
\text { fitting two slopes }\end{array}$ & 1 & 27.05 & 0.7941 & & & \\
\hline $\begin{array}{l}\text { Reduction- } \\
\text { fitting two means }\end{array}$ & 1 & $1,745.88$ & $51.2415 * * *$ & & & \\
\hline $\begin{array}{l}\text { Pooled error } \\
\text { SS about two lines }\end{array}$ & 46 & 34.07 & & 46 & 40.49 & \\
\hline \multicolumn{7}{|l|}{ Protein:DNA } \\
\hline $\begin{array}{l}\text { Reduction- } \\
\text { fitting two lines }\end{array}$ & 2 & $5,394.61$ & 0.2714 & 2 & $225,865.81$ & $10.1624 * * *$ \\
\hline $\begin{array}{l}\text { Reduction- } \\
\text { fitting two slopes }\end{array}$ & & & & 1 & $43,723.63$ & 1.9673 \\
\hline $\begin{array}{l}\text { Reduction- } \\
\text { fitting two means }\end{array}$ & & & & 1 & $408,008.00$ & $18.3576 * * *$ \\
\hline $\begin{array}{l}\text { Pooled error } \\
\text { SS about two lines }\end{array}$ & 58 & $19,879.03$ & & 58 & $22,225.55$ & \\
\hline
\end{tabular}

${ }^{1}$ See table I, footnotes 3 through 7 .

${ }^{2} \mathrm{df}=$ degrees of freedom.

$* P<0.025$.

** $P<0.01$.

$* * * P<0.001$. 


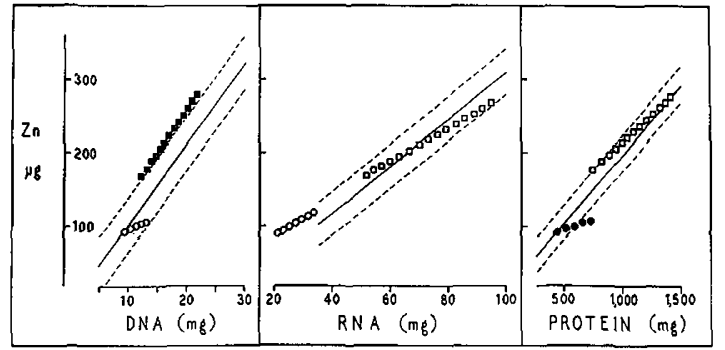

Fig. 2. Relation of $\mathrm{Zn}$ with DNA, RNA, and protein. Solid line represents the control. Dashed line represents the standard deviation. The equation to each normal relation is reported in the text. $\bigcirc \bullet:$ hypophysectomized rats. $\square$ : calorie-restricted rats. Solid symbols represent significant difference with controls by covariance analysis; open symbols represent nonsignificance. The length of the lines represent the range of data for each group.

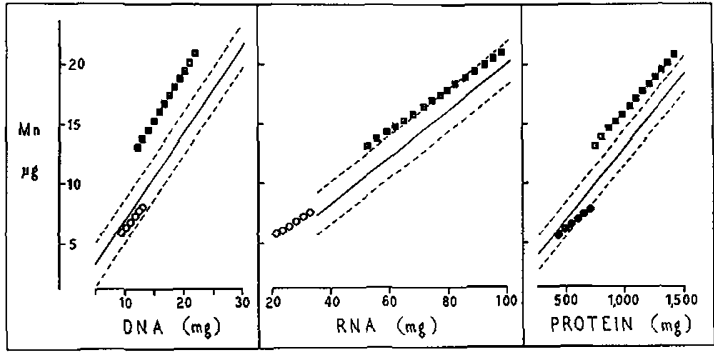

Fig. 3. Relation of Mn with DNA, RNA, and protein. Solid line represents the control. Dashed line represents the standard deviation. The equation to each normal relation is reported in the text. $\bigcirc \bullet:$ hypophysectomized rats. $\square$ : : calorie-restricted rats. Solid symbols represent significant difference with controls by covariance analysis; open symbols represent nonsignificance. The length of the lines represent the range of data for each group.

Table III. Covariance analysis

\begin{tabular}{|c|c|c|c|c|c|c|}
\hline \multirow[b]{3}{*}{ Source $^{1}$} & \multicolumn{6}{|c|}{ Control rats versus } \\
\hline & \multicolumn{3}{|c|}{ Hypophysectomized rats } & \multicolumn{3}{|c|}{ Calorie-restricted rats } \\
\hline & $\mathrm{df}^{2}$ & $\begin{array}{l}\text { Mean } \\
\text { square }\end{array}$ & $F$ & $\mathrm{df}$ & $\begin{array}{l}\text { Mean } \\
\text { square }\end{array}$ & $F$ \\
\hline \multicolumn{7}{|l|}{$\mathrm{Zn}: \mathrm{DNA}$} \\
\hline $\begin{array}{l}\text { Reduction- } \\
\text { fitting two lines }\end{array}$ & 2 & $1,272.45$ & 1.2106 & 2 & $10,471.14$ & $9.5233 * * *$ \\
\hline $\begin{array}{l}\text { Reduction- } \\
\text { fitting two slopes }\end{array}$ & & & & 1 & 78.98 & 0.0718 \\
\hline $\begin{array}{l}\text { Reduction- } \\
\text { fitting two means }\end{array}$ & & & & 1 & $20,863.30$ & $18.9749 * * *$ \\
\hline $\begin{array}{l}\text { Pooled error } \\
\text { SS about two lines }\end{array}$ & 57 & $1,051.09$ & & 57 & $1,099.52$ & \\
\hline \multicolumn{7}{|l|}{$\mathrm{Zn}: \mathrm{RNA}$} \\
\hline $\begin{array}{l}\text { Reduction- } \\
\text { fitting two lines }\end{array}$ & 2 & $1,390.15$ & 2.0739 & 2 & $2,325.47$ & 3.2563 \\
\hline $\begin{array}{l}\text { Pooled error } \\
\text { SS about two lines }\end{array}$ & 46 & 670.32 & & 46 & 714.14 & \\
\hline \multicolumn{7}{|l|}{ Zn:protein } \\
\hline $\begin{array}{l}\text { Reduction- } \\
\text { fitting two lines }\end{array}$ & 2 & $3,034.12$ & $6.2863^{* *}$ & 2 & $1,192.80$ & 2.3659 \\
\hline $\begin{array}{l}\text { Reduction- } \\
\text { fitting two slopes }\end{array}$ & 1 & $2,061.04$ & 4.2702 & & & \\
\hline $\begin{array}{l}\text { Reduction- } \\
\text { fitting two means }\end{array}$ & 1 & $4,007.21$ & $8.2024 * *$ & & & \\
\hline $\begin{array}{l}\text { Pooled error } \\
\text { SS about two lines }\end{array}$ & 58 & 482.66 & & 58 & 504.16 & \\
\hline
\end{tabular}

${ }^{1}$ See table I, footnotes 3 through 7.

${ }^{2} \mathrm{df}=$ degrees of freedom.

$* * P<0.01$.

$* * * P<0.001$. 
Manganese (table IV)

The Mn levels for given DNA or RNA values did not differ from the normal range in the hypophysectomized rat, but $\mathrm{Mn}$ was slightly reduced with respect to protein $(P<0.025)$. The levels were elevated above normal in rats subjected to calorie restriction $(P<0.001$ for DNA or protein; $P<0.005$ for RNA).

Ratios with DNA (table V)

Although the above comparisons were made using total amounts of DNA, RNA, protein, $\mathrm{Zn}$, and $\mathrm{Mn}$ in liver, consideration was also given to the ratios with
DNA. In general, although the ratios were linearly related, the regression lines were not defined clearly. Correlation coefficients of 0.53-0.72 were found with proportionately high variances. Ratios present a statistical problem when both numerator and denominator are random variables that may be changing at different rates. Interpretation of the results from analysis of covariance using ratios can be difficult or misleading.

In the work presented here, however, it can be demonstrated that $\mathrm{Zn}$ and $\mathrm{RNA}$ retain a normal relation per unit DNA in the two abnormal situations con-

Table IV. Covariance analysis

\begin{tabular}{|c|c|c|c|c|c|c|}
\hline \multirow[b]{3}{*}{ Source $^{1}$} & \multicolumn{6}{|c|}{ Control rats versus } \\
\hline & \multicolumn{3}{|c|}{ Hypophysectomized rats } & \multicolumn{3}{|c|}{ Calorie-restricted rats } \\
\hline & $d f^{2}$ & $\begin{array}{l}\text { Mean } \\
\text { square }\end{array}$ & $F$ & $\mathrm{df}$ & $\begin{array}{l}\text { Mean } \\
\text { square }\end{array}$ & $F$ \\
\hline \multicolumn{7}{|l|}{ Mn:DNA } \\
\hline $\begin{array}{l}\text { Reduction- } \\
\text { fitting two lines }\end{array}$ & 2 & 2.3950 & 0.9659 & 2 & 140.59 & $45.7292 * * *$ \\
\hline $\begin{array}{l}\text { Reduction- } \\
\text { fitting two slopes }\end{array}$ & & & & 1 & 2.11 & 0.6869 \\
\hline $\begin{array}{l}\text { Reduction- } \\
\text { fitting two means }\end{array}$ & & & & 1 & 279.06 & $90.7714 * * *$ \\
\hline $\begin{array}{l}\text { Pooled error } \\
\text { SS about two lines }\end{array}$ & 57 & 2.4796 & & 57 & 3.07 & \\
\hline \multicolumn{7}{|l|}{ Mn:RNA } \\
\hline $\begin{array}{l}\text { Reduction- } \\
\text { fitting two lines }\end{array}$ & 2 & 1.0011 & 0.4307 & 2 & 14.18 & $5.1050 * *$ \\
\hline $\begin{array}{l}\text { Reduction- } \\
\text { fitting two slopes }\end{array}$ & & & & 1 & 3.44 & 1.2367 \\
\hline $\begin{array}{l}\text { Reduction- } \\
\text { fitting two means }\end{array}$ & & & & 1 & 24.93 & $8.9732 * *$ \\
\hline $\begin{array}{l}\text { Pooled error } \\
\text { SS about two lines }\end{array}$ & 46 & 2.3244 & & 46 & 2.78 & \\
\hline \multicolumn{7}{|l|}{ Mn:protein } \\
\hline $\begin{array}{l}\text { Reduction- } \\
\text { fitting two lines }\end{array}$ & 2 & 8.5518 & $4.7868 *$ & 2 & 43.09 & $18.8867 * * *$ \\
\hline $\begin{array}{l}\text { Reduction- } \\
\text { fitting two slopes }\end{array}$ & 1 & 1.5011 & 0.8420 & 1 & 1.57 & 0.6877 \\
\hline $\begin{array}{l}\text { Reduction- } \\
\text { fitting two means }\end{array}$ & 1 & 15.6024 & $8.7516 * *$ & 1 & 84.61 & $37.0857 * * *$ \\
\hline $\begin{array}{l}\text { Pooled error } \\
\text { SS about two lines }\end{array}$ & 58 & 1.7828 & & 58 & 2.28 & \\
\hline
\end{tabular}

${ }^{1}$ See table I, footnotes 3 through 7.

${ }^{2} \mathrm{df}=$ degrees of freedom.

$* P<0.025$.

** $P<0.01$.

*** $P<0.001$. 
sidered (fig. 4). The three groups, therefore, were combined, as before, to calculate the following equation:

$$
\frac{\mathrm{Zn}}{\mathrm{DNA}}=3.951+2.001 \frac{\mathrm{RNA}}{\overline{\mathrm{DNA}}}
$$

where $\mathrm{N}=66$ and variance $=0.6524$. The relation of $\mathrm{Mn} / \mathrm{DNA}$ to RNA/DNA are included in table $\mathrm{V}$ for comparison.

\section{Discussion}

Data from several studies support a possible role of $\mathrm{Zn}$ in protein synthesis $[12,13,18]$; however, as pointed out by Fox and HaRrison [8], there have been no definite studies in animals. The present study demonstrates that liver RNA content follows liver $\mathrm{Zn}$ content over a variety of experimental conditions that are known to affect the subsequent synthesis of protein. The implication is that $\mathrm{Zn}$ has a primary role in protein synthesis and work by other investigators in lower forms of life supports this thesis. Moreover, a close relation is suspected between $\mathrm{Zn}$ and RNA for unicellular organisms and for plants [12, 24-26].

Altmann et al. [1], in studies with Chorella pyrenoidosa, showed an approximate but parallel increase of $\mathrm{Zn}$ and messenger RNA (mRNA), suggesting an influence of $\mathrm{Zn}$ ions on RNA synthesis. The growth of Euglenx

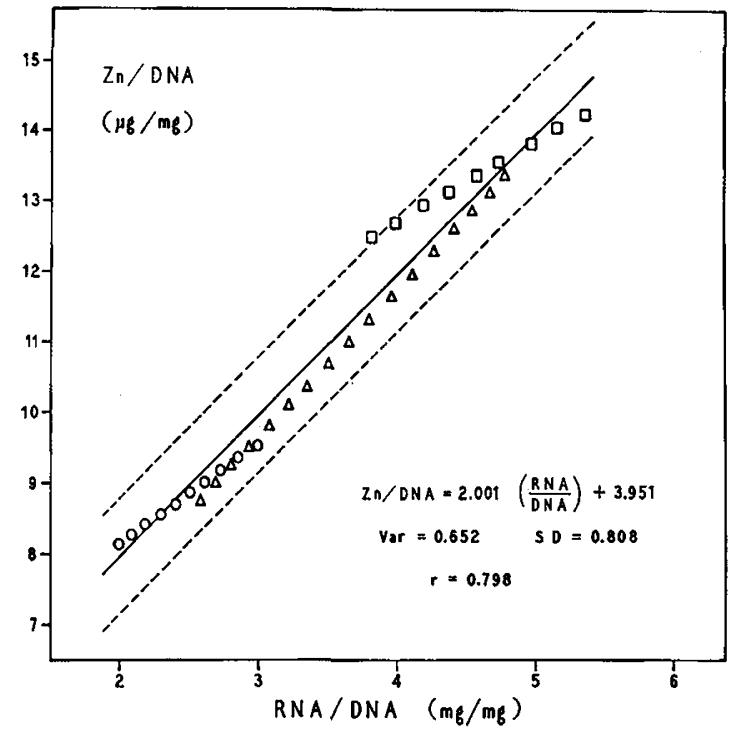

Fig.4. Solid line represents the relation of $\mathrm{Zn} / \mathrm{DNA}$ to RNA/DNA calculated for control and experimental groups. Dashed lines represent standard deviation. $\Delta$ : control rats. $O$ : hypophysectomized rats. $\square$ : calorierestricted rats. Open symbols represent no significant difference with controls by covariance analysis. The length of the lines represent the range of data for each group.

Table $V$. Covariance analysis

\begin{tabular}{|c|c|c|c|c|c|c|}
\hline \multirow[b]{3}{*}{ Source ${ }^{1}$} & \multicolumn{6}{|c|}{ Control rats versus } \\
\hline & \multicolumn{3}{|c|}{ Hypophysectomized rats } & \multicolumn{3}{|c|}{ Calorie-restricted rats } \\
\hline & $d f^{2}$ & $\begin{array}{c}\text { Mean } \\
\text { square }\end{array}$ & $F$ & $\mathrm{df}$ & $\begin{array}{c}\text { Mean } \\
\text { square }\end{array}$ & $F$ \\
\hline \multicolumn{7}{|l|}{$\mathrm{Zn} / \mathrm{DNA}: \mathrm{RNA} / \mathrm{DNA}$} \\
\hline $\begin{array}{l}\text { Reduction- } \\
\text { fitting two lines }\end{array}$ & 2 & 1.2073 & 0.6908 & 2 & 4.1831 & 2.3767 \\
\hline $\begin{array}{l}\text { Pooled error } \\
\text { SS about two lines }\end{array}$ & 45 & 1.7477 & & 45 & 1.7600 & \\
\hline \multicolumn{7}{|l|}{ Mn/DNA:RNA/DNA } \\
\hline $\begin{array}{l}\text { Reduction- } \\
\text { fitting two lines }\end{array}$ & 2 & 0.0040 & 0.9417 & 2 & 0.1478 & $26.6450 * * *$ \\
\hline $\begin{array}{l}\text { Reduction- } \\
\text { fitting two slopes }\end{array}$ & & & & 1 & 0.0069 & 1.2381 \\
\hline $\begin{array}{l}\text { Reduction- } \\
\text { fitting two means }\end{array}$ & & & & 1 & 0.2887 & $52.0519 * * *$ \\
\hline $\begin{array}{l}\text { Pooled error } \\
\text { SS about two lines }\end{array}$ & 45 & 0.0043 & & 45 & 0.0055 & \\
\hline
\end{tabular}

${ }^{1}$ See table I, footnotes 3 through 7 .

${ }^{2} \mathrm{df}=$ degrees of freedom.

$* * * P<0.001$. 
gracilis is proportional to the $\mathrm{Zn}$ concentration within the cell. In zinc-deficient Euglena, the earliest metabolic 'lesion' is a failure of RNA formation followed by interference with protein and DNA synthesis [19, 21].

Ribonucleic acid is capable of binding significant quantities of metal ions. WACKER and VALLEE [22] have made systematic studies of nucleic acid from diverse sources and have demonstrated that relatively large amounts of metals were firmly bound to these nucleic acids. It has been suggested that these metals have a role in determining and stabilizing the configuration of these nucleic acids and in maintaining their biological activity $[6,9,16,20]$. Commercial RNA samples were reported to contain metals that interfered with both the assay of ribonuclease and ribonuclease inhibitor $[20,27]$. Such metals were identified as $\mathrm{Zn}$ and $\mathrm{Cu}$ [27].

Though the present investigation concerns $\mathrm{Zn}$ and $\mathrm{Mn}$, it is clear that other trace metals are important. Relation with nucleic acids may prove informative. For example, when calories are restricted, does the change in Mn within the liver cell reflect a change in mitochondrial mass as suggested by others [7]?

Until recently the main emphasis concerning the role of $\mathrm{Zn}$ in cell growth had fallen on the $\mathrm{Zn}$-sensitive enzymes. Growth retardation that occurred because of $\mathrm{Zn}$ deprivation had been explained as the result of altered activity of these enzymes [17]. Whatever the role of $\mathrm{Zn}$ in growth, it would not appear to be a simple influence on $\mathrm{Zn}$-enzyme interaction. When $\mathrm{Zn}$-deficient $\mathcal{N}$ eurospora were repleted with $\mathrm{Zn}$, alcohol dehydrogenase (a $\mathrm{Zn}$ metalloenzyme) activity increased appreciably but a source of nitrogen was required-as though protein synthesis must have occurred concomitantly [18]. Wood and SrbLy [28] found that the activity of carbonic anhydrase (a $\mathrm{Zn}$ metalloenzyme) in oat leaves was reduced by a deficiency of $\mathrm{Zn}$, the inhibition being related to the blocking of protein synthesis and not to a lack of sufficient $\mathrm{Zn}$ to activate the enzyme. KessLer [11] demonstrated that the ribonuclease activity of apple leaves increased sharply with a decreased $\mathrm{Zn}$ content below $15 \mathrm{ppm}$. Studies of Zn deficiency in Euglena and other organisms indicated that the RNA molecule was curiously unstable [18]. Other studies demonstrated that RNA molecules containing $\mathrm{Zn}$ inhibited ribonuclease activity [27]. It is possible that $\mathrm{Zn}$ is necessary to protect liver RNA from attack by nuclease.

Recent studies of MACAPINLAC et al. [14] using the testes of $\mathrm{Zn}$-deficient rats demonstrated a reduced total content of RNA and protein, but unaltered incorporation of adenosine-14 $\mathrm{C}$ and leucine- ${ }^{14} \mathrm{C}$ into RNA and protein, respectively. They suggested that an increase in RNA and protein catabolism may occur in $\mathrm{Zn}$ deficiency rather than a decrease in synthesis.
Work on infants suffering from protein malnutrition (kwashiorkor) has demonstrated reduced RNA/DNA and $\mathrm{Zn} / \mathrm{DNA}$ levels in muscle [4]; increased DNA, RNA, and $\mathrm{Zn}$ values occurred with rehabilitation. WARREN et al. [23], in a preliminary communication, record low values for $\mathrm{Zn}$ in the liver of children with marasmus and kwashiorkor. The present study demonstrates that in calorie-restricted rats (without protein deficiency) liver protein, RNA, $\mathrm{Zn}$, and $\mathrm{Mn}$, when related to total DNA, are all increased. Thus, these two types of restricted nutrition give rise to differential effects in tissues [10].

While $\mathrm{Zn}$ deficiency may exist in mammals as a definite entity, the hypothesis can be made that in protein deficiency, as with other situations, RNA content of the cell will fluctuate with the $\mathrm{Zn}$ content [3].

Glearly, further work must be done to elucidate the relation of $\mathrm{Zn}$ to RNA during other experimental conditions such as in simple $\mathrm{Zn}$ deficiency.

\section{Summary}

The relation of the metals, $\mathrm{Zn}$ and $\mathrm{Mn}$, with DNA, RNA, and protein in the livers of normal, hypophysectomized, and calorie-restricted rats are examined. Statistical methods utilizing regression analysis and analysis of covariance demonstrate a strong and continuous relation between $\mathrm{Zn}$ and RNA. The biological implications of these findings are discussed.

\section{References and Notes}

1. Altmann, H.; Fetter, F. and Kaindr, K. : Effect of zinc ions on mRNA synthesis in chorellar cells. Z. Naturforsch. B 23: 395 (1968).

2. Gheer, D. B. and Graystone, J.E.: The action of insulin, growth hormone, and epinephrine on cell growth in liver, muscle, and brain of the hypophysectomized rat. Pediat. Res. 3: 77 (1969).

3. Cheex, D.B. and Graystone, J.E.: Changes in enzymes (GOT and $\mathrm{GDH}$ ) and metals ( $\mathrm{Zn}, \mathrm{Mn}$ and $\mathrm{Mg}$ ) in liver of rats during endocrine imbalance and caloric restriction. Pediat. Res. 3: 433 (1969).

4. Cheer, D.B.; Hrld, D.E.; Cordano, A. and Graham, G.: Malnutrition in infancy: changes in muscle and adipose tissue before and after rehabilitation. Pediat. Res. 4: 135 (1970).

5. Gheek, D. B. ; Powell, G. K. ; Reba, R. and FeldMAN, M.: Manganese, copper and zinc in rat muscle and liver cells and in thyroid and pituitary insufficiency. Bull. Johns Hopk. Hosp. 118: 338 (1966).

6. Gheo, P. G. ; Friesar, B.S. and Sinsheimer, R. L. : 
Biophysical studies of infectious ribonucleic acid from tobacco mosaic virus. Proc.nat.Acad.Sci., Wash. 45: 305 (1959).

7. Cotzias, G.C. and Greenough, J.J.: The high specificity of the manganese pathway through the body. J. clin. Invest. 37: 1298 (1958).

8. Fox, M.R.S. and HARRISON, B. N. : Zinc deficiency and plasma proteins; in: A. PrasAd: Zinc metabolism, chapt. 10, p. 187 (Thomas, Springfield, IL 1966).

9. FuWA, K.; WAcker, W.E.C.; DruYan, R.; Bartholomay, A.F. and Vallee, B.L.: Nucleic acids and metals. II. Transition metals as determinants of the configuration of ribonucleic acids. Proc. nat. Acad. Sci., Wash. 46: 1298 (1960).

10. Graystone, J.E. and Cheek, D.B.: The effects of reduced caloric intake and increased insulininduced caloric intake on the cell growth of muscle, liver, and cerebrum and on skeletal collagen in the postweanling rat. Pediat. Res. 3: (1969).

11. KessLer, B. : Ribonuclease as a guide for the determination of zinc deficiency in orchard trees; in: Plant analysis and fertilizer problems, p. 314 (American Institute of Biological Sciences, Washington, DG 1961).

12. Kessler, B. and Monselise, S.P.: Studies on ribonuclease, ribonucleic acid and protein synthesis in healthy and zinc-deficient citrus leaves. Physiol. Plant. 12: 1 (1959).

13. Macapinlac, M.P.; Pearson, W.N. and Darby, W.J.: Some characteristics of zinc deficiency in the albino rat; in: A. PRASAD: Zinc metabolism, chapt.8, p. 142 (Thomas, Springfield, IL 1966).

14. Macapinlac, M.P.; Pearson, W.N.; Barney, G.H. and DARBY, W.J.: Protein and nucleic acid metabolism in the testes of zinc-deficient rats. J. Nutr. 95: 569 (1968).

15. Mellits, E.D.: Statistical methods, in: D.B. GHEEK: Human growth, chapt.2, p.19 (Lea \& Febiger, Philadelphia 1968).

16. Mertz, W.: Ghromium occurrence and function in biological systems. Physiol. Rev. 49: 163 (1969).

17. Prasad, A. S.; Oberleas, D.; Wolf, P. and HorwIrz, J.P.: Studies on zinc deficiency: Changes in trace element and enzyme activities in the zinc deficient rat. J. clin. Invest. 46: 549 (1967).

18. PRICE, D. A.: Control of processes sensitive to zinc in plants and microorganisms; in: A. PRASAD : Zinc metabolism, chapt.5, p. 69 (Thomas, Springfield, IL 1966).
19. Schneider, E. and Price, C.A.: Decreased ribonucleic acid levels: A possible cause of growth inhibition in zinc deficiency. Biochim. biophys. Acta 55: 406 (1962).

20. Singer, B. and Fraenkel-Conrat, H.: Enzyme resistance of complexes with ribonucleic acid with metals. Biochemistry 1: 852 (1962).

21. WACKer, W.E.C.: Nucleic acids and metals. III. Changes in nucleic acid, protein, and metal content as a consequence of zinc deficiency in Euglena gracilis. Biochemistry 1: 859 (1962).

22. Wacker, W.E.G. and VAllee, B.L.: Nucleic acids and metals. I. Chromium, manganese, nickel, iron and other metals in ribonucleic acid from diverse biological sources. J. biol. Chem. 234: 3257 (1959).

23. Warren, P.J.; Hansen, J.D.L. and Lehmann, B. H. : The concentration of copper, zinc and manganese in the liver of African children with marasmus and kwashiorkor. Proc. Nutr. Soc.28:6A(1969).

24. WEGNeR, W.S. and Romano, A.H.: Zinc stimulation of RNA and protein synthesis in Rhizopus nigricans. Science 142: 1669 (1963).

25. Winder, F.G. and Denneny, J. M. : Effect of iron and zinc on nucleic acid and protein synthesis in Myobacterium smegmatis. Nature, Lond. 184: 742 (1959).

26. Winder, F.G. and O'Hara, G.: Effects of iron deficiency and zinc deficiency on the composition of Myobacterium smegmatis. Biochem. J. 82: 98 (1962).

27. Wojnar, R.J. and Roth, J.S.: Metal ions in ribonucleic acid: Their nature and interference with the assay for ribonuclease and ribonuclease inhibitor. Biochim. biophys. Acta 87: 17 (1964).

28. Wood, J. G. and Sxbly, P. M. : Carbonic anhydrase activity in plants in relation to zinc content. Austr. J. Sci. Res. B5: 244 (1952).

29. The complete data have been placed in the Welch Medical Library, Johns Hopkins University School of Medicine, Baltimore, Maryland.

30. Hormone Assay Laboratories, Chicago, IL.

31. Purina Laboratory Ghow, Ralston-Purina Company, St.Louis, MO.

32. Supported by Public Health Service Research Grant no. HD00126-06 from the National Institute of Child Health and Human Development.

33. Requests for reprints should be addressed to DoNALd GHeEk, M.D., The Johns Hopkins Hospital, 601 North Broadway, Baltimore, MD21205 (USA). 34. Accepted for publication October 3, 1969. 